\title{
Analisis Kepuasan Masyarakat Terhadap Penggunaan Aplikasi SiBisa dengan Pendekatan TAM
}

\author{
Enita Rosmika, Azulaidin, T Lyza Tahura Chairunnisa* \\ Universitas Amir Hamzah, Medan, Indonesia \\ Email: ${ }^{1}$ nitarose60.nr@gmail.com, ${ }^{2}$ Azul.aidin@yahoo.com, ${ }^{3, *}$ tengkulyza@gmail.com \\ Email Penulis Korespondensi: tengkulyza@gmail.com \\ Submitted: 21/11/2021; Accepted: 28/11/2021; Published: 30/11/2021
}

\begin{abstract}
Abstrak-Pemanfaat dari kemajuan teknologi pada saat ini sudah banyak dimanfaatkan oleh banyak sektor seperti kesehatan, pendidikan, pemerintahan atau bahkan pelayanan publik dari suatu instansi. Pada dasaranya instansi pemerintahan mengadopsi dari pada prinsip good government atau ketatapemerintahgan yang baik. Hal yang selalu menjadi fokus utama pada pemerintahan kota tertuju pada pelayanan pada Dinas Kependudukan dan Pencatatan Sipil (DISDUKCAPSIL). Proses yang dilakukan pada pencatatan sipil memiliki fokus yang utama didasarkan dengan proses yang dilakukan cukup lama dan juga mengharuskan masyarakat harus bolak - balik datang untuk melakukan proses pencatatan sipil. Pemko Medan memiliki fokus visi misi terhadap peningkatan pelayanan publik. Aplikasi SiBisa yang dikembangkan oleh Pemko Medan untuk mempermudah bagi masyarakat Kota Medan untuk mengurus administrasi kependudukan. Tetapi keberhasilan dan juga tolak ukur dari pemerintahaan bukan hanya saja dari kemudahan pelayan an publik tetapi juga kepuasan terhadap pelayanan publik. Penelitian ini bertujuan untuk mengkurut tingkat kepuasan masyarakat terhadap pelayanan aplikasi SiBisa dengan melakukan pendekatan model Metode Technology of Acceptance Model (TAM). Dengan respoden sebanyak 30 orang dari para pengguna aplikasi SiBisa. Hasil pada peneliitan bahwa masyarakat sudah puas dengan kemudahan dan pelayanan dari aplikasi SiBisa. Hal tersebut didukung dengan pengaruh variabel secara stimulant sebesar 75,2\%
\end{abstract}

Kata Kunci: Kepuasan; Masyarakat; Aplikasi SiBisa; Metode TAM

Abstract-Beneficiaries of technological advances at this time have been widely used by many sectors such as health, education, government or even public services from an agency. Basically, government agencies adopt the principles of good government or good governance. What has always been the main focus of city government is on services to the Population and Civil Registration Service (DISDUKCAPSIL). The process carried out on civil registration has a main focus based on the process that is carried out for a long time and also requires the community to come back and forth to carry out the civil registration process. Pemko Medan has a vision and mission focus on improving public services. The Si Bisa application was developed by the Medan City Government to make it easier for the people of Medan City to take care of population administration. But the success and also the benchmark of government is not only from the ease of public services but also satisfaction with public services. This study aims to measure the level of community satisfaction with the service of the Sibisa application by approaching the Technology of Acceptance Model (TAM) method. With as many as 30 respondents from Sibisa application users. The results of the research show that the community is satisfied with the convenience and service of the Sibisa application. This is supported by the influence of the variable stimulant of $75.2 \%$.

Keywords: Satisfaction; Community; SiBisa Application; TAM Method

\section{PENDAHULUAN}

Perkembangan teknologi tidak dapat dihindarkan pada masa sekarang ini, perkembangan teknologi yang begitu cepat dapat mempermudah seluruh proses kegiatan yang dilakukan oleh seluruh kaum masyarakat(Novita \& Helena, 2021). Sekarang ini teknologi memiliki peran yang begitu penting dalam mensukseskan kegiatan - kegiatan yang dilakukan baik secara formal ataupun juga non-formal. Dengan kehadiran kemajuan teknologi tersebut masyarakat tidak lagi memerlukan waktu yang lama untuk menyelesaikan proses kegiatan yang dilakukan(Raharjo \& Prasetyo, 2016).

Pemanfaat dari kemajuan teknologi pada saat ini sudah banyak dimanfaatkan oleh banyak sektor seperti kesehatan, pendidikan, pemerintahan atau bahkan pelayanan publik dari suatu instansi. Dari pemanfaatan teknologi akan memudahkan untuk mendapatkan sebuah informasi yang bersifat transparan kepada masyarakat luas, selain itu dengan teknologi tersebut mampu meningkatkan efisiensi, kecepatan dan jangkauan terhadap penyampaian serta kemudahan informasi(Hendarto, 2020). Terkhususnya pada instansi pemerintahan yang melakuakan pelayanan publik terhadap masyrakat(Nurdiani et al., 2019).

Pada dasaranya instansi pemerintahan mengadopsi dari pada prinsip good government atau ketatapemerintahgan yang baik. Kepemerintahan yang baik merupakan penyelengaraan terhadap manajemen pembangunan yang bertanggungjawab, demokratis, efektif juga efisien. Pemerintah juga dituntut untuk memiliki prinsip mengikutsertakan masyarakat juga pihak swasta, transparansi, kesetaraan dan seluruh masyarakat memliki kesempatan dan hak yang sama dalam bermasyarakat(Kholifah \& Setiyono, 2018).

Hal yang selalu menjadi fokus utama pada pemerintahan kota tertuju pada pelayanan pada Dinas Kependudukan dan Pencatatan Sipil (DISDUKCAPSIL). Dinas kependudukan dan catatan sipil atau Dispendukcapil adalah dinas yang menangani tentang pencatatan kependudukan. Pelayanan publik menurut Undang-Undang Republik Indonesia Nomor 25 Tahun 2009 tentang Pelayanan Publik adalah kegiatan atau rangkaian kegiatan dalam rangka pemenuhan kebutuhan pelayanan sesuai peraturan perundangundangan bagi setiap warga negara dan penduduk atas barang, jasa, atau pelayanan administratif yang disediakan oleh pemerintah(Defra Alchindi Q et al., n.d.).

Pada Dinas Kependudukan dan Pencatatan Sipil (DISDUKCAPSIL) memberikan pelayanan terhadap pencatatan sipil seperti penerbitan e-KTP, penerbitan Akta Kelahiran, Akta Perkawinan, Aktan Kematian dan juga Akta Perceraian. 
Proses yang dilakukan pada pencatatan sipil memiliki fokus yang utama didasarkan dengan proses yang dilakukan cukup lama dan juga mengharuskan masyarakat harus bolak - balik datang untuk melakukan proses pencatatan sipil(APRIANSYAH, 2016).

Proses yang lama dilakukan dikarenakan banyaknya masyarakat yang melakukan proses pencatatan sipil diwaktu bersamaan dengan tenaga kerja pelayanan yang terbatas. Hal tersebut menjadi sorotan pada instansi pemerintahan, begitu juga dengan Pemerintahan Kota Medan (PEMKO Medan). Pemko Medan memiliki fokus visi misi terhadap peningkatan pelayanan publik. Hal itu yang mendasari bagi Pemko Medan untuk melakukan inovasi dengan memanfaatkan peranan teknologi tersebut, dimana pada saat ini Pemko Medan memiliki aplikasi SiBisa.

Aplikasi SiBisa yang dikembangkan oleh Pemko Medan untuk mempermudah bagi masyarakat Kota Medan untuk mengurus administrasi kependudukan. Dengan aplikasi tersebut masyarakat tidak diharuskan lagi untuk datang ke Disdukcapcil untuk melakukan proses administrasi pada pencatatan kependudukan. Aplikasi SiBisa tersebut memudahkan bagi masyarakat untuk melakukan proses pencatatan kependudukan dilakukan secara online dimanapun dan kapanpun.

Tetapi keberhasilan dan juga tolak ukur dari pemerintahaan bukan hanya saja dari kemudahan pelayanan publik tetapi juga kepuasan terhadap pelayanan publik. Sebuah teknologi aplikasi dapat dikatakan berhasil ketika teknologi tersebut dapat diterima oleh pengguna ataupun masyarakat(Hartatik \& Budihartanti, 2020). Teknologi harus memiliki fungsi kegunaan, kemudahaan, sikap dan juga intensi. Kepuasan terhadap penggunaan teknologi atau teknologi tersebut dapat diterima oleh pengguna merupakan sebagai bahan evaluasi untuk melakukan inovasi dikemudian hari(Afni \& Akil, 2017).

Kepuasan sendiri memiliki arti sebagai perasaan senang atau juga kecewa yang timbul dikarenakan adanya perbandingan kinerja yang dipersepsikan terhadap ekpektasi. Kepuasan juga merupakan konsekuensi juga akibat atas pengalaman dari suatu pihak terhadap kemampuan pihak lainnya untuk memenuhi norma - norma ataupun aturan aturan(Aritonang et al., 2019). Terwujudnya pelayanan administrasi yang berkualitas merupakan salah satu ciri kepemerintahan yang baik sebagai tujuan dari pendayagunaan aparatur negara. Untuk itu, aparatur negara diharapkan semakin efisien dan efektif melaksanakan tugas dan tanggungjawab dalam menyelenggarakan pemerintahan, pembangunan dan pengayoman masyarakat(Ardarsyah \& F, 2016).

Untuk mengukur hal itu dapat dilakukan dengan pendekatan dari Metode Technology Acceptance Model (TAM). Technology of Acceptance Model (TAM) merupakan sebuah model pendekatan yang digunakan untuk mengukur serta menganalis terhadap factor-faktor yang mempengaruhi diterimanya sebuah sistem informasi(Adha et al., 2021). Technology of Acceptance Model (TAM) merupakan model yang mengaitkan antara keyakinan kognitif dengan sikap dan perilaku individual terhadap penerimaan teknologi. Technology of Acceptance Model (TAM) telah diakui sebagai model yang kuat untuk menjelaskan dan memprediksi penerimaan individu terhadap teknologi.

Pada penelitian ini akan dilakukan penilaian kepuasan masyarakat terhadap penggunaan aplikasi SiBisa berdasarkan dengan pendekatan dari Metode Technology of Acceptance Model (TAM) untuk menentukan aspek - aspek yang dinilai atau diukur pada hipotesis penelitian.

\section{METODE PENELITIAN}

\subsection{Manajemen Pelayanan Publik}

Manajemen dapat diartikan sebagai serangkaian proses maupun kegiatan pemanfaatan sumberdaya yang dimiliki untuk mencapai tujuan yang ditetapkan. Pembangunan perlu dilihat dari perspektif manajemen, yaitu sebagai sebuah proses value creation yang berkesinambungan, apapun alasannya, siapapun penguasanya, bagaimanapun tantangannya. Jika semua fungsi dalam suatu manajemen pemerintahan berjalan efisien dan efektif maka akan mendorong tindakan yang tertib, teratur, sistematis, cepat, dinamis dan tepat sasaran. Sesuai dengan fungsi pokok pemerintah yaitu memberikan pelayanan publik maka pada gilirannya akan tersedia dan terselenggara dengan baik dan memuaskan masyarakat. Kegiatan pelayanan umum dalam konteks ini merupakan perwujudan dan penjabaran

Dari tugas dan fungsi aparat pemerintah dalam rangka penyelenggaraan tugastugas umum pemerintahan maupun pembangunan(Windyani et al., 2014).

Pada awalnya konsep pelayanan prima timbul dari kreativitas para pelaku bisnis, yang kemudian diikuti oleh organisasi-organisasi nirlaba dan instansi pemerintah, sehingga dewasa ini pelayanan prima tidak lagi hanya milik dunia bisnis tetapi milik semua orang. Pelayanan publik sebagai setiap kegiatan yang dilakukan oleh pemerintah terhadap sejumlah manusia yang memiliki setiap kegiatan yang menguntungkan dalam suatu kumpulan Atau kesatuan dan menawarkan kepuasan meskipun hasilnya tidak terikat pada suatu produk secara fisik.

Secara formal, lingkup pengertian pelayanan publik dalam Kepmenpan Nomor 63 Tahun 2003 dirumuskan sebagai segala kegiatan pelayanan yang dilaksanakan oleh penyelenggara pelayanan publik sebagai upaya pemenuhan kebutuhan penerima pelayanan maupun pelaksanaan ketentuan peraturan perundang-undangan. Dengan demikian, pelayanan publik dapat dikatakan harus senantiasa diaplikasikan jika sudah diatur dalam perundangan sekalipun publik tidak memanfaatkan secara maksimal. Kualitas pelayanan dapat pula didefinisikan sebagai sistem manajemen strategik dan integratif yang melibatkan semua manajer dan karyawan serta menggunakan metode-metode kualitatif dan kuantitatif untuk memperbaiki secara berkesinambungan proses-proses organisasi, agar dapat memenuhi dan melebihi kebutuhan, keinginan dan harapan pelanggan(Windyani et al., 2014). 


\subsection{Kepuasan Pengguna}

Kepuasan penggunaan informasi menurut merupakan sikap multidimensional dari pengguna terhadap aspek-aspek yang berbeda dalam sistem infomasi. Kepuasan penggunaan informasi adalah seberapa jauh informasi yang disediakan untuk memenuhi kebutuhan informasi yang mereka butuhkan. Dari pengertian di atas dapat disimpulkan bahwa kepuasan pengguna menggambarkan keselarasan antara harapan seseorang dan hasil yang diperoleh dengan adanya suatu sistem dimana tempat orang tersebut.

Kepuasan pengguna akhir sistem informasi merupakan salah satu tolok ukur keberhasilan sistem informasi akuntansi. Hal ini didasarkan pada teori nilai harapan yang dikembangkan oleh Ajzen dan Fishbein dalam Chai dkk (2004). Menurut teori ini, variabel eksternal mempengaruhi keyakinan tentang hasil yang dihubungkan dengan perilaku yang dilakukan yang dilain pihak membentuk sikap terhadap perilaku yang dibentuk. Di lain pihak, sikap mempengaruhi keinginan untuk membentuk perilaku dan pada akhirnya mempengaruhi perilaku itu sendiri. Kepuasan dalam situasi yang tetap adalah perasaan seseorang atau sikap terhadap sekelompok faktor yang mempengaruhi situasi tersebut.

Kepuasan penggunaan merupakan penilaian menyangkut apakah kinerja suatu sistem informasi itu relatif bagus atau jelek, dan juga apakah sistem informasi yang disajikan cocok atau tidak cocok dengan tujuan pemakainya. Secara umum kepuasan pengguna adalah hasil yang dirasakan pengguna mengenai kinerja suatu sistem yang dioperasikan sesuai dengan harapan mereka. Pengguna merasa puas apabila harapan mereka terpenuhi. Pengguna yang puas cenderung tetap loyal lebih lama dan relatif lebih sering menggunakan.

\subsection{Metode Technology Acceptance Model (TAM)}

Technology Acceptance Model (TAM) atau dalam bahasa indonesia disebut sebagai Model penerimaan teknologi adalah model yang mengadopsi theory of reasoned action (TRA) teori tindakan yang beralasan dengan satu premis bahwa reaksi dan persepsi seseorang terhadap sesuatu hal, akan menentukan sikap dan perilaku orang tersebut. Reaksi dan persepsi pengguna Teknologi Informasi (TI) akan mempengaruhi sikapnya dalam penerimaan terhadap teknologi tersebut teori ini dikembangkan oleh Fishbein dan Ajzen (1975). Teori tentang penggunaan sistem teknologi informasi yang dianggap sangat berpengaruh dan umumnya digunakan untuk menjelaskan penerimaan individual terhadap penggunaan sistem teknologi informasi(Yuliana et al., 2016)

TAM kemudian digunakan untuk menerangkan perilaku penerima individu terhadap teknologi informasi yang menyimpulkan bahwa persepsi kegunaan dan persepsi kemudahan penggunaan adalah penentu utama penggunaan teknologi. TAM telah diakui sebagai model yang kuat untuk menjelaskan dan memprediksi penerimaan individu terhadap teknologi. Menurut Davis (1989) Technology Acceptance Model (TAM) memprediksi penerimaan penggunaan terhadap teknologi berdasarkan pengaruh dari dua faktor kognitif yaitu persepsi kegunaan (perceived usefulness) dan persepsi kemudahan (perceived ease of use).

Di dalam teori TAM terdapat faktor yang mempengaruhi penerimaan dan pengguna dalam menggunalan sistem informasi yaitu:

1. Kegunaan (Perceived Usefulness)

Merupakan suatu tingkatan dimana seseorang percaya bahwa menggunakan sistem tersebut dapat meningkatkan

kinerja dalam bekerja.

2. Kemudahan (Perceived ease of use)

Merupakan suatu tingkatan dimana seseorang percaya bahwa menggunakan sistem tersebut tidak perlu bersusah payah artinya mudah dikontrol dan fleksibel.

3. Sikap (Attitude toward using technology)

Merupakan perasaan positif atau negatif dari seseorang dalam menggunakan sistem.

4. Intensi (Behavior Intention to use)

Merupakan suatu kecenderungan perilaku untuk menggunakan suatu teknologi.

5. Penggunaan teknologi sesungguhnya (Actual technology use)

Salah satu faktor yang dapat mempengaruhinya adalah persepsi pengguna terhadap kemanfaatan dan kemudahan penggunaan TI sebagai suatu tindakan yang beralasan dalam konteks pengguna teknologi, sehingga alasan seseorang dalam melihat manfaat dan kemudahan penggunaan TI menjadikan tindakan/perilaku orang tersebut sebagai tolok ukur dalam penerimaan sebuah teknologi. Pengguna yang potensial percaya bahwa aplikasi tertentu berguna, mungkin mereka, pada saat yang sama percaya bahwa sistem ini terlalu sulit untuk digunakan dan manfaat yang di dapat dari penggunaan yang melebihi upaya menggunakan aplikasi. Artinya, di samping manfaat atau kegunaannya, penerapan sistem teknologi informasi akan dipengaruhi juga oleh kemudahan yang dirasa penggunaan (perceived ease of use). Model Technology Acceptance Model (TAM) dapat digambarkan sebagai berikut :

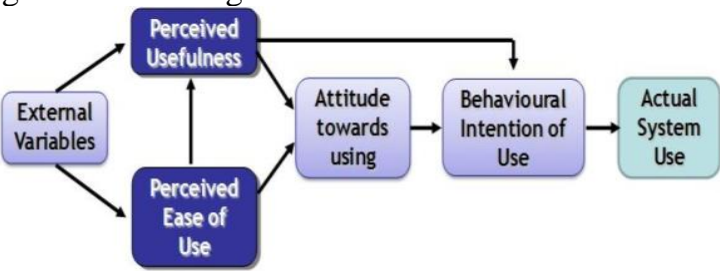

Gambar 1. Model Technology Acceptance Model (TAM) 


\subsection{Penelitian Terdahulu}

Berikut ini adalah hasil penelitian yang telah dilakukan oleh beberapa peneliti baik di Indonesia maupun negara lain seperti yang terlihat pada tabel berikut ini:

Tabel 1. Penelitian Terdahulu

\begin{tabular}{|c|c|c|c|c|c|}
\hline No & Nama & & Judul & Hasil & Sumber \\
\hline 1 & $\begin{array}{l}\text { (Utama } \\
\text { Indriani, 2019) }\end{array}$ & $\&$ & $\begin{array}{lrr}\text { Analisis } & \text { Kepuasan } & \text { Pengguna } \\
\text { Aplikasi } & \text { Ojek } & \text { Online } \\
\text { Menggunakan } & \text { Metode } \\
\text { Technology Acceptance Model } \\
\text { (Tam) }\end{array}$ & $\begin{array}{l}\text { Hasil penelitian menunjukan ber- } \\
\text { dasarkan peng-ukurn pendekatan } \\
\text { yang dilakuakan didapatkan hasil } \\
\text { positif terhadap penggunaan aplikasi } \\
\text { ojek online }\end{array}$ & $\begin{array}{l}\text { Jurnal Riset } \\
\text { Informatika } \\
\text { Vol. } 1 \text { No. } 3\end{array}$ \\
\hline 2 & $\begin{array}{l}\text { (Yuliana et } \\
\text { 2016) }\end{array}$ & al., & $\begin{array}{l}\text { Analisis Kepuasan Pegawai } \\
\text { Terhadap Layanan Unit Sistem } \\
\text { Informasi Menggunakan } \\
\text { Technology Acceptance Model } \\
\text { Di Pt Kereta Api Indonesia } \\
\text { (Persero) }\end{array}$ & $\begin{array}{l}\text { Hasil pengujian atas model yang } \\
\text { diajukan menunjukkan hasil yang } \\
\text { baik. Berdasarkan penelitian yang } \\
\text { telah dilakukan pada pegawai PT } \\
\text { Kereta Api Indonesia (Pesero) di } \\
\text { Unit Komersial dan Keuangan, } \\
\text { mengenai pengujian } \text { Model } \\
\text { Kepuasan Pegawai Terhadap } \\
\begin{array}{l}\text { Layanan Unit Sistem Informasi, } \\
\text { maka }\end{array}\end{array}$ & $\begin{array}{l}\text { Jurnal } \\
\text { Informatika } \\
\text { Vol.3 No. } 2\end{array}$ \\
\hline 3 & $\begin{array}{l}\text { (Widowati } \\
\text { Budihartanti, } \\
\text { 2019) }\end{array}$ & $\&$ & $\begin{array}{l}\text { Analisis Kepuasan Pengguna } \\
\text { Terhadap Aplikasi Traveloka } \\
\text { Dengan Menerapkan Metode } \\
\text { TAM (Technology Acceptance } \\
\text { Model) }\end{array}$ & 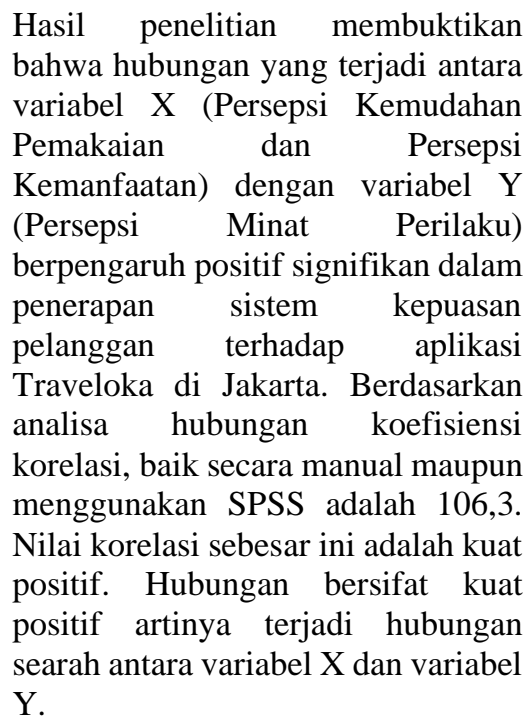 & $\begin{array}{l}\text { Jurnal } \\
\text { Prosisko } \\
\text { Vol. } 6 \text { N0. } 2\end{array}$ \\
\hline 4 & $\begin{array}{l}\text { (Nurdiani et } \\
\text { 2019) }\end{array}$ & & $\begin{array}{lr}\text { Pengaruh } & \text { Penerapan Sistem } \\
\text { CPNS Online } & \text { Terhadap } \\
\text { Kepuasan } & \text { Masyarakat } \\
\text { Menggunakan Metode TAM }\end{array}$ & $\begin{array}{l}\text { Berdasarkan hasil penelitian dari } \\
\text { pengaruh penerapan sistem cpns } \\
\text { online terhadap kepuasan } \\
\text { masyarakat diperoleh hasil bahwa : } \\
\text { Terdapat pengaruh yang signifikan } \\
\text { antara variabel kualitas sistem } \\
\text { terhadap kepuasan masyarakat, tidak } \\
\text { terdapat pengaruh yang signifikan } \\
\text { antara kualitas informasi terhadap } \\
\text { kepuasan masyarakat. Terdapat } \\
\text { pengaruh yang signifikan antara } \\
\text { variabel kualitas layanan terhadap } \\
\text { kepuasan masyarakat }\end{array}$ & $\begin{array}{l}\text { Jurnal } \\
\text { Techno Nusa } \\
\text { Mandiri Vol } \\
16 \text { No. } 1\end{array}$ \\
\hline
\end{tabular}

\subsection{Pendekatan Penelitian}

Penelitian ini berlandaskan penelitan yang menggunakan data primer diambil langsung melalui responden. Jenis data yang digunakan dan diolah merupakan data kuantitatif. Responden pada penelitan sebanyak 30 orang. Kemudahan, sikap, norma, kontrol dan lingkungan digunakan sebagai variable penelitian untuk mengukur SiBisa pada masyarakat.

\subsection{Teknik Analisis Data}

Jenis data dalam penelitian ini adalah data kuantitatif yang. Data dikumpulkan menggunakan survey / kuesioner dan data diolah menggunakan SPSS. Kuesioner berisikan pertanyaan berdasarkan dengan Skala Likert. Teknis analisis data yang 
digunakan dalam penelitian ini yaitu dengan menggunakan analisis komparatif yaitu suatu teknik dengan menggunakan uji rata-rata atau uji beda dengan perlakuan yang tidak sama.

1. Hipotesis :

Ho : $\mu_{\mathrm{A}}=\mu_{\mathrm{B}}$ (Masyarakat sudah mendapatkan kemudahan terhadap pelayanan publik)

Ha : $\mu_{\mathrm{A}} \neq \mu_{\mathrm{B}}$ (Masyarakat sudah puas dengan pelayanan terhadap aplikasi SiBisa)

2. Uji statistik yang digunakan adalah uji $\mathrm{t}$ :

$$
\mathrm{t}_{\text {hitung }}=\frac{\bar{X}_{A}-\bar{X}_{B}}{\sqrt{\frac{s_{A}}{n_{A}}+\frac{s_{B}}{n_{B}}}} \text { atau } \mathrm{t}_{\text {hitung }}=\frac{\bar{X}_{1}-\bar{X}_{2}}{s \sqrt{\frac{1}{n_{1}}+\frac{1}{n_{2}}}}
$$

Dibandingkan dengan $\mathrm{t}_{\text {tabel }}= \pm \mathrm{t}(\alpha / 2, \mathrm{nA}+\mathrm{nB}-2$ dengan derajat kesalahan $\alpha=10 \%)$

\section{Kriteria uji}

Terima $\mathrm{H}_{0}$, jika $-\mathrm{t}_{\mathrm{t}} \leq \mathrm{th} \leq \pm \mathrm{t}_{\mathrm{t}}$ hal lain tolak $\mathrm{h}_{0}$ dengan kurva distribusi normal

4. Kesimpulan

Terima atau tolak Ho. Karena penelitian mengelola data dengan menggunakan software maka dikatakan signifikan, jika nilai sig $<$ dari kesalahan $\alpha=10 \%$.

\section{HASIL DAN PEMBAHASAN}

Hasil penelitian merupakan hasil akhir gabungan dari latar belakang masalah, hipotesis, pengumpulan data dan pengujian literatur dengan menggunakan metode analisis data yang dilaksanakan pada objek penelitian untuk mencari titik penyelesaian permasahalan yang dihadapai.

Dari penjelasan diatas Metode Survey ialah dengan menyebarkan kuesioner secara online yang melibatkan secara langsung terhadap pengguna aplikasi SiBisa sebagai aplikasi pencatatan sipil sebanyak 30 kuesioner. Berikut gambaran umum secara menyeluruh terkait hasil pengumpulan data responden yang menjadi subjek penelitian ini yang berdasarkan usia

Tabel 2. Karakteristik Responden

\begin{tabular}{|c|c|c|c|c|}
\hline No & Karakteristik & Responden & Total & $\%$ \\
\hline \multirow{6}{*}{1} & \multirow{6}{*}{ Usia } & $<20$ Tahun & 5 & $17 \%$ \\
\hline & & 21 - 25 Tahun & 8 & $27 \%$ \\
\hline & & 26 - 30 Tahun & 8 & $27 \%$ \\
\hline & & 31 - 35 Tahun & 6 & $20 \%$ \\
\hline & & 36 - 40 Tahun & 2 & $7 \%$ \\
\hline & & $>41$ Tahun & 1 & $3 \%$ \\
\hline \multirow{6}{*}{2} & \multirow{6}{*}{ Pendidikan } & SMA/SMK & 11 & $37 \%$ \\
\hline & & D3 & 3 & $10 \%$ \\
\hline & & D4 & 1 & $3 \%$ \\
\hline & & S1 & 13 & $43 \%$ \\
\hline & & S2 & 2 & $7 \%$ \\
\hline & & S3 & 0 & $0 \%$ \\
\hline \multirow{6}{*}{3} & \multirow{6}{*}{ Pekerjaan } & Wiraswasta & 13 & $43 \%$ \\
\hline & & PNS & 3 & $10 \%$ \\
\hline & & TNI/Polri & 3 & $10 \%$ \\
\hline & & Pelajar/Mahasiswa & 6 & $20 \%$ \\
\hline & & Karyawan Swasta & 4 & $13 \%$ \\
\hline & & Lain-lain & 1 & $3 \%$ \\
\hline \multirow{3}{*}{4} & & 1 Kali & 21 & $70 \%$ \\
\hline & Intensitas Penggunaan SiBisa & $2 \mathrm{~s} / \mathrm{d} 5$ Kali & 9 & $30 \%$ \\
\hline & & $>5$ Kali & 0 & $0 \%$ \\
\hline
\end{tabular}

Dari karakteristik responden yang didapatkan pada tabel diatas menunjukan bahwa dari 30 responden yang digunakan pada penelitian ini adalah berkisaran umur 21-25 Tahun dan 26-30 Tahun. Hal tersebut menggambarkan bahwasannya mayoritas pengguna digitalisasi adalah generasi yang sudah terbiasa menggunakan teknologi dalam aktifitasnya. Selain itu pada tingkat pendidikan pengguna SiMBA mayoritas memiliki latar belakang pendidikan S1 dan SMA/SMK.

Karakteristik lainnya yang didapat dari responden pengguna SiBisa $43 \%$ adalah wiraswasta. Kemudian Pelajar/Mahasiswa dengan tingkat persentase adalah 20\%. Hasil karakteristik responden lainnya secara umum pengguna dari pada SiBisa masih menggunakan layanan sebanyak 1 Kali. 


\subsection{Uji Validitas dan Reabilitas Instrumen}

Sebelum dilakukan penyebaran kuesioner kepada para responden, terlebih dahulu dilakukan uji validtas dan juga realibilitas terhadap instrument yang digunakan

Tabel 3. Uji Validitas dan Reliabilitas Instrumen

\begin{tabular}{lccccc}
\hline \multicolumn{1}{c}{ Variabel } & Koefisien & R Tabel & Validtas & $\begin{array}{c}\text { Cronbach's } \\
\text { Alpha }\end{array}$ & Reliabilitas \\
\hline Kemudahan & 0,749 & & Valid & & \\
Sikap & 0,835 & & Valid & & Realiabel \\
Norma & 0,643 & 0,361 & Valid & 0,78 & \\
Kontrol & 0,712 & & Valid & & \\
Lingkungan & 0,753 & & Valid & & \\
\hline
\end{tabular}

Jumlah responden yang digunakan pada penelitian sebanyak 30 orang, maka untuk nilai $\mathrm{R}$ tabel adalah 0,361. Dari tabel di atas tampak bahwa hasil Uji Validitas dan Uji Reliabilitas. Untuk Kemudahan mendapatkan nilai koefisien 0,749 $>$ 0,361 maka instrument penelitian untuk Kemudahan sudah dinyatakan valid. Kemudian untuk Sikap mendapatkan nilai koefisien 0,835 > 0,361 instrument penelitian untuk Sikap sudah dinyatakan valid. Kemudian untuk Norma mendapatkan nilai koefisien 0,643 > 0,361 instrument penelitian untuk Norma sudah dinyatakan valid. Kemudian untuk Kontrol mendapatkan nilai koefisien 0,712 > 0,361 instrument penelitian untuk Kontrol sudah dinyatakan valid. Kemudian untuk Lingkungan mendapatkan nilai koefisien 0,753 > 0,361 instrument penelitian untuk Lingkungan sudah dinyatakan valid. Kemudian pengukuran terhadap nilai reliablitias dan didapatkan nilai koefisien $0,78>0,361$. Maka dapat dinyatakan bahwa hasil sudah realiabel dan dapat disebarkan terhadap responden dan dilakukan pengumpulan data.

\subsection{Uji T dan Uji F}

Setelah dilakukannya Uji Validitas dan juga Uji Reliabilitas pada instrument penelitian. Tahapan langkah yang dilakukan seterusnya adalah melakukan pengujian terhadap Uji T dan Uji F. Uji T dan Uji F dilakukan untuk melakukan pengujian terhadap hipotesa. Apakah hipotesa yang sudah dijabarkan dapat diterima ataupun ditolak. Adapun untuk Uji T dapat dilihat pada tabel berikut

Tabel 4. Uji T

\begin{tabular}{|c|c|c|c|c|c|c|}
\hline \multicolumn{7}{|c|}{ Coefficients $^{\mathrm{a}}$} \\
\hline \multirow[b]{2}{*}{ Model } & & Unstandardized & Coefficients & $\begin{array}{l}\text { Standardized } \\
\text { Coefficients }\end{array}$ & & \\
\hline & & B & Std. Error & Beta & $\mathrm{t}$ & Sig. \\
\hline 1 & (Constant) & .291 & .819 & & .355 & .726 \\
\hline & Kemudahan (X1) & .090 & .142 & .099 & .634 & .532 \\
\hline & Sikap (X2) & .154 & .165 & .172 & 2.933 & .001 \\
\hline & Norma (X3) & .447 & .146 & .572 & 3.054 & .004 \\
\hline & Kontrol (X4) & -.026 & .110 & -.036 & -.239 & .813 \\
\hline & Lingkungan (X5) & .315 & .111 & .421 & 2.842 & .003 \\
\hline
\end{tabular}

Berdasarkan dari hasil Uji T yang telah dilakukan bahwasannya nilai batas untuk Uji T adalah 2,060 dengan nilai sig $<0,05$. Berdasarkan hasil yang telah didapatkan bahwasaannya secara keseluruhan $\mathrm{H}_{0}$ diterima dan $\mathrm{H}_{1}$ diterima. Bahwasannya seluruh variabel yang digunakan pada penelitian berpengaruh terhadap penggunaan aplikasi SiBisa.

Tabel 5. Uji F

\begin{tabular}{llrrrrr}
\hline & & \multicolumn{3}{c}{ ANOVA $^{\mathbf{a}}$} & & \\
Model & & Sum of Squares & df & Mean Square & F & Sig. \\
\hline 1 & Regression & 7.815 & 5 & 1.563 & 6.198 & $.001^{\text {b }}$ \\
& Residual & 6.052 & 24 & .252 & & \\
& Total & 13.867 & 29 & & & \\
\hline
\end{tabular}

a. Dependent Variable: Puas (Y)

b. Predictors: (Constant), Lingkungan (X5), Kontrol (X4), Sikap (X2), Kemudahan (X1), Norma (X3)

Berdasarkan dari hasil Uji F yang telah dilakukan bahwasannya nilai batas untuk Uji $\mathrm{F}$ adalah 2,53 dengan nilai sig $<0,05$. Berdasarkan hasil yang telah didapatkan bahwasaannya secara keseluruhan $\mathrm{H}_{0}$ diterima dan $\mathrm{H}_{1}$ diterima. Bahwasannya seluruh variabel yang digunakan pada penelitian berpengaruh terhadap penggunaan aplikasi SiBisa. 


\section{KESIMPULAN}

Setelah dilakukan seluruh proses anlisa pada penelitian maka didapatkan hasil penelitian bahwasannya penggunaan terhadap kepuasan pelayanan secara signifkan dipengaruhi oleh Kemudahan, Sikap, Norma dan Kontrol. Penelitian ini bertujuan untuk mengkaji sejauh manakah tingkat kepuasan masyarakat terhadap pelayanan aplikasi SiBisa dengan pendekatan Metode TAM (Technology Acceptance Model). Hasil yang didapatkan bahwasannya secara keseluruhan Hipotesis diterima dengan hasil bahwa Masyarakat sudah puas dengan pelayanan terhadap aplikasi SiBisa dan Masyarakat sudah mendapatkan kemudahan terhadap pelayanan publik. Hal tersebut didukung dengan pengaruh variabel secara stimulant sebesar $75,2 \%$.

\section{REFERENCES}

Adha, F. L. Y., Hamzah, M. L., Maita, I., Megawati, \& Marsal, A. (2021). Analisis Penerimaan Pengguna Dapodik Sekolah Dasar Kecamatan Tampan Menggunakan Model TAM dan EUCS. Jurnal Sains, Teknologi Dan Industri, 18(2), 196-205.

Afni, N., \& Akil, I. (2017). Analisis Tingkat Kepuasan Pengguna Commuter Line Terhadap Commuter Vending Machine dengan Metode Technology Acceptance Model Pada. Simnasiptek 2017, 1980, 7-13.

APRIANSYAH, W. (2016). ANALISIS INDEKS KEPUASAN MASYARAKAT TERHADAP PELAYANAN PUBLIK PADA DINAS KEPENDUDUKAN DAN CATATAN SIPIL (DISDUKCAPIL) KABUPATEN PANDEGLANG. In UNIVERSITAS SULTAN AGENG TIRTAYASA. UNIVERSITAS SULTAN AGENG TIRTAYASA SERANG.

Ardarsyah, R., \& F, M. N. (2016). ANALISIS KUALITAS PELAYANAN SISTEM INFORMASI AKADEMIK TERHADAP KEPUASAN PENGGUNA SISTEM DI POLITEKNIK POS INDONESIA MENGGUNAKAN METODE TECHNOLOGY ACCEPTENCE MODEL (TAM) (Studi Kasus : Politeknik Pos Indonesia). Jurnal Lppm Politeknik Pos Indonesia, 11(1), 1-8.

Aritonang, R. P., Sumarlin, \& Kaban, R. (2019). Kajian Tingkat Kepuasan Mahasiswa Terhadap Sistem Informasi Berbasis Web dengan Metode Technology Acceptance Model(TAM). Tekesnos, 1(1), 40-47.

Defra Alchindi Q, Larasati, E., \& Rihandoyo. (n.d.). ANALISIS KUALITAS PELAYANAN PEMBUATAN E-KTP DI KECAMATAN PEDURUNGAN.

Hartatik, S. R., \& Budihartanti, C. (2020). Analisis Kepuasan Pengguna Terhadap Penerapan Aplikasi Go-Jek Dengan Menggunakan Metode TAM ( Technology Acceptance Model ). Jurnal PROSISKO, 7(1), 1-7. http://ejurnal.lppmunsera.org/index.php/PROSISKO/article/view/1653

Hendarto, S. F. (2020). Analisis Kepuasan Pengguna pada Media atau Platform Penyedia Tiket Film Aplikasi Tix ID di Yogyakarta dengan Pendekatan TAM (Technology Acceptance Model). https://dspace.uii.ac.id/handle/123456789/23739

Kholifah, R. N., \& Setiyono, B. (2018). SURVEY KEPUASAN MASYARAKAT TERHADAP PELAYANAN E-KTP DI KECAMATAN TEMBALANG KOTA SEMARANG. 1-10. http://ejournal-s1.undip.ac.id/index.php/

Novita, D., \& Helena, F. (2021). Analisis Kepuasan Pengguna Aplikasi Traveloka Menggunakan Metode Technology Acceptance Model ( TAM ) Dan End-User Computing Satisfaction ( EUCS ). Jtsi, 2(1), 22-37.

Nurdiani, S., Ade Safitri, R., \& Riana, D. (2019). Pengaruh Penerapan Sistem CPNS Online Terhadap Kepuasan Masyarakat Menggunakan Metode TAM. Jurnal Techno Nusa Mandiri, 16(1), 59-64.

Raharjo, A. T., \& Prasetyo, A. (2016). Analisis Pengaruh Kemudahan Penggunaan Sopp Terhadap Kepuasan Kerja Pegawai Dengan Pendekatan Tam. Jurnal Sistem Informasi STMIK Antar Bangsa, 5(2), 129-138.

Utama, N. P., \& Indriani, F. (2019). Analisis Kepuasan Pengguna Aplikasi Ojek Online Menggunakan Metode Technology Acceptance Model (Tam). Jurnal Riset Informatika, 1(3), 139-146. https://doi.org/10.34288/jri.v1i3.39

Widowati, A. Y., \& Budihartanti, C. (2019). Analisis Kepuasan Pengguna Terhadap Aplikasi Traveloka Dengan Menerapkan Metode TAM (Technology Acceptance Model). Jurnal Prosisko, 6(2), 109-116.

Windyani, A. R., Hubeis, A. V. S., \& Fahmi, I. (2014). Analisis Kepuasan Masyarakat terhadap Pembuatan Akta Kelahiran di Depok, Jawa Barat. 32, 32.

Yuliana, Y., Sanjaya, R., \& Shobary, M. N. (2016). Analisis Kepuasan Pegawai Terhadap Layanan Unit Sistem Informasi Menggunakan Technology Acceptance Model Di Pt Kereta Api Indonesia (Persero). Jurnal Informatika, 3(2), 290-298 https://www.academia.edu/36039139/ANALISIS_KEPUASAN_PEGAWAI_TERHADAP_LAYANAN_UNIT_SISTEM_INF ORMASI_MENGGUNAKAN_TECHNOLOGY_ACCEPTANCE_MODEL_DI_PT_KERETA_API_INDONESIA_PERSER $\mathrm{O}_{-}$ 